\title{
Rosai-Dorfman disease of vertebra: Case report and literature review
}

\author{
Zoran Igrutinovic ${ }^{1,2}$, Rasa Medovic ${ }^{1}$, Slavica Markovic ${ }^{1,2}$, Gordana Kostic ${ }^{1,2}$, Zorica \\ Raskovic $^{1,2}$, Jelena Tanaskovic-Nestorovic ${ }^{1,2}$, Marija Radovanovic ${ }^{1,2}$, Biljana Vuletic ${ }^{1,2}$ \\ ${ }^{1}$ Pediatric Clinic, Clinical Centre Kragujevac; ${ }^{2}$ Faculty of Medical Sciences, University of Kragujevac, Kragujevac, Serbia. \\ E-mail: rasamedovic@gmail.com \\ Received: 8th March 2016, Revised: 17th May 2016, Accepted: 18th July 2016
}

\begin{abstract}
SUMMARY: Igrutinovic Z, Medovic R, Markovic S, Kostic G, Raskovic Z, Tanaskovic-Nestorovic J, Radovanovic M, Vuletic B. Rosai-Dorfman disease of vertebra: Case report and literature review. Turk J Pediatr 2016; 58: 566-571.

Rosai-Dorfman disease is a rare benign histiocytic disorder that arises predominantly in lymph nodes with fever and malaise, but can affect various organs, with or without lymphadenopathy. Solitary extranodal skeletal lesions are extremely rare. Herein, we describe a case of isolated disease of thoracic spine, with vertebral body fracture.
\end{abstract}

A 14-year-old girl presented with cervical back pain for about one month as the only symptom. There was no lymphadenopathy. Results of laboratory tests were within reference ranges. The radiological examinations revealed collapse, osteolytic lesion and compressive fracture, which reduced vertical diameter of $\mathrm{C} 4$ vertebral body. The patient made a complete recovery after a limited C4 laminectomy, spondylodesis C3/C5 vertebra and biopsy of the lesion. Histologically, nonspecific cellular milieu and atypical histiocytic proliferation with emperipolesis, with CD68 and S100 positivity, confirmed a diagnosis of Rosai-Dorfman disease.

Isolated extranodal skeletal Rosai-Dorfman disease should be considered among the differential diagnoses of similar changes, such as Langerhans cell histiocytosis, Erdheim-Cheister disease, eosinophilic granuloma, osteomyelitis, metastasis and lymphoma.

Key words: back pain, laminectomy, emperipolesis, sinus histiocytosis.

Rosai-Dorfman disease (RDD), also called sinus histiocytosis with massive lymphadenopathy (SHML) is a rare, sporadic disease which most commonly affects young adults and adolescents. The disease usually presents as painless, massive cervical and paratracheal lymphadenopathy in up to $90 \%$ of patients. Systemic symptoms are also common ${ }^{1-3}$.

Approximately 1100 patients have been reported with this disorder. About $45 \%$ of cases had at least one site of extranodal involvement as well as lymph node involvement, and about $20-25 \%$ of cases had extranodal involvement only. The most frequent extranodal sites are skin, soft tissue, nasal and orbital cavity, bone, salivary glands and central nervous system ${ }^{1-4}$.

Skeletal lesions are usually multifocal and mainly associated with lymphadenopathy and disease in other organs ${ }^{4}$. A review of the literature reveals approximately 50 cases with solitary bone lesion as only manifestation of the disease ${ }^{4}$. To the authors' best knowledge; solitary lesions in the spinal column are described in 14 cases $^{5-18}$. Vertebral body fracture is an extremely rare manifestation of $\mathrm{RDD}$, which was previously reported in only one case ${ }^{17}$.

\section{Case Report}

We presented a 14-year-old girl with intermittent cervical back pain and difficulties in mobility of the neck for about a month after gym exercises in school. There were no injuries of that part of the body or surrounding soft-tissue palpable mass. She had no other systemic symptoms such as fever, weight 
loss, chills or malaise. We did not discovered anything relevant from the past medical history. She did not have any surgical interventions before. There was no specific finding on physical and neurological examination. There was no lymphadenopathy. Results of routine hematologic and biochemical laboratory tests include erythrocyte sedimentation rate, Creactive protein $(\mathrm{CRP})$ and serum total proteins, albumin and immunoglobulins were within normal reference ranges.

A plain radiological examination of the cervical spine revealed physiological lordosis with collapse and osteolytic lesion of C4 vertebra body. The remaining bone structures were without significant changes (Figures $1 \mathrm{a}$ and $1 \mathrm{~b}$ ).

Preoperative computed tomography (CT) scan showed modified bone structure with osteolytic lesions of C4 vertebral body, which were extended to the right to processus transversus. Compressive fracture reduced the vertical diameter of the $\mathrm{C} 4$ vertebral body and made a deformation of the upper body surface in which the interventricular discus $\mathrm{C} 3 / \mathrm{C} 4$ was minimally impacted. There were also mild signs of anteriorly subluxation of C3 vertebral body.

Magnetic resonance (MR) image of cervical spine demonstrated reduced vertical diameter (4 $\mathrm{mm}$ ) of C4 corpus due to complete spontaneous collapse of $\mathrm{C} 4$ vertebral body. In the posterior part of the collapsed vertebral body we identified the vertical fracture crack. The dislocated bone fragment in the dorsomedial direction was narrowing the spinal canal (8 $\mathrm{mm}$ ) and compressed the spinal cord, but without myelopathy. Based on the intensity of MR signals we could not determine the cause of the collapse with certainty. Intervertebral discus $\mathrm{C} 3-\mathrm{C} 4$ and $\mathrm{C} 4-\mathrm{C} 5$ were intact. The remaining bone structures of the cervical spine and first five thoracic vertebral bodies were without significant changes.

CT of the chest, abdomen and pelvis was performed for preoperative evaluation and showed normal findings.

Corporectomia of $\mathrm{C} 4$ with decompression of the spinal canal from anterior side of $\mathrm{C} 3$ to $\mathrm{C} 5$ vertebral bodies was performed. The removed part of vertebra was sent for histopathologic analysis. Part of the left iliac crest was used for autotransplantation and reconstruction as spondylodesis C3 to C5 vertebra was performed. She was discharged from hospital at postoperative 10 days without complications and additional medications, except some pain killers.

Histopathologic study of the lesion revealed atypical histiocytic proliferation with focal infiltration of medium to large histiocytes showing emperipolesis (Figures $2 \mathrm{a}$ and $2 \mathrm{~b}$ ). Nonspecific cellular milieu (lymphocytes, plasma cells, individual eosinophils and neutrophils) was also present. PAS and ZielhnNeelsen staining has not proved the existence of microorganisms. Immunochemistry stain showed that these histiocytes were positive for CD68, S-100, Lysozym and CD163, but negative for CDla. In situ hybridization for EBV it had also showed negative.

Since then, the girl is in good general state with normal physical findings and laboratory analyses. However, after two years, upon one routine control we detected thrombocytopenia without manifested hemorrhagic syndrome. The investigations have verified that it was an immune thrombocytopenic purpura (ITP). On treatment with corticosteroids and i.v. immunoglobulins we achieved partial response. The disease has entered the chronic phase with signs of hemorrhagic syndrome. After a year, splenectomy, was performed but without improvement and after that the girl was treated with protocols of cytostatics and with rituximab, again with partial response. Now, she is in a stable phase of the disease (ITP), without therapy and also without any other complications related to the RDD and submitted to regular examinations by the hematologist in charge.

\section{Discussion}

Sinus histiocytosis with massive lymphadenopathy or Rosai-Dorfman disease was first described by Destombes in 1965 and officially classified in 1969 by Rosai and Dorfman $^{19}$. It is primarily a disease of childhood and early adulthood (mean age 20 years). No specific gender, ethnic, or socioeconomic predilection is encountered ${ }^{1,2}$. Considering its rare occurrence, approximately 1100 patients have been reported with this disorder, many are single case reports or descriptions of a small series of patients. 

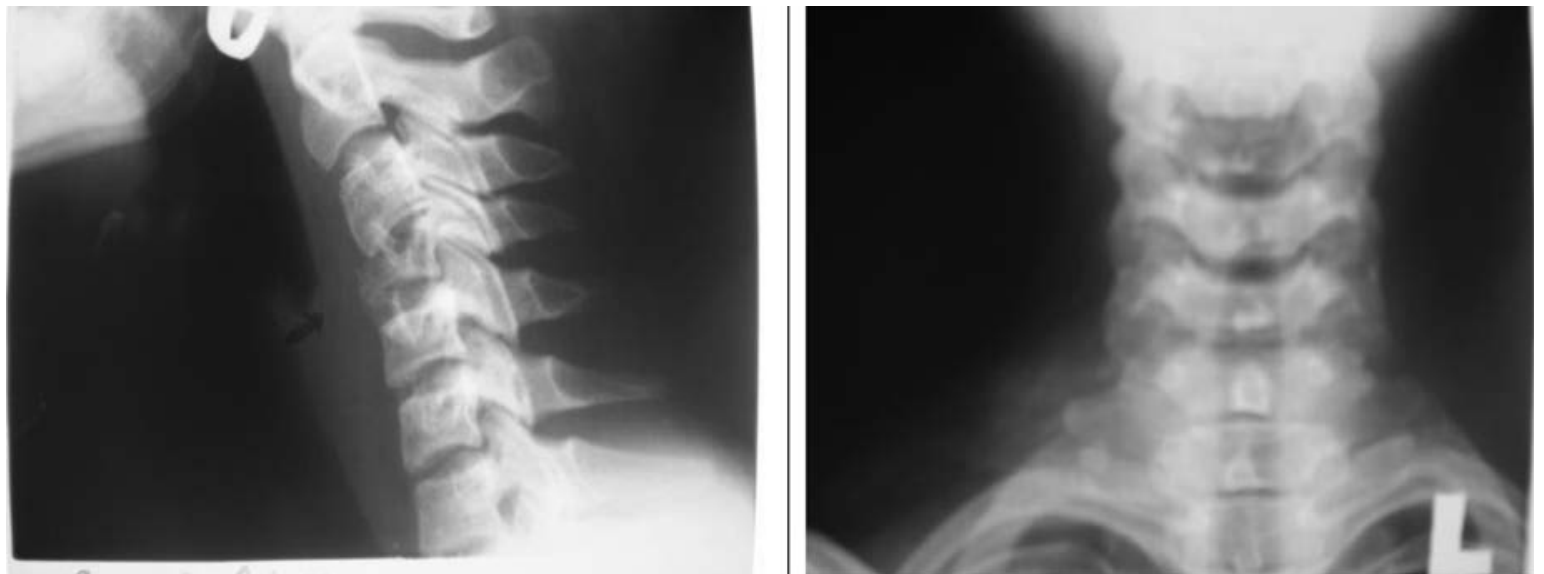

Fig. 1a and 1b. Radiological PA and profile findings of cervical spine showed collapse and osteolytic lesion of C4 vertebra body.
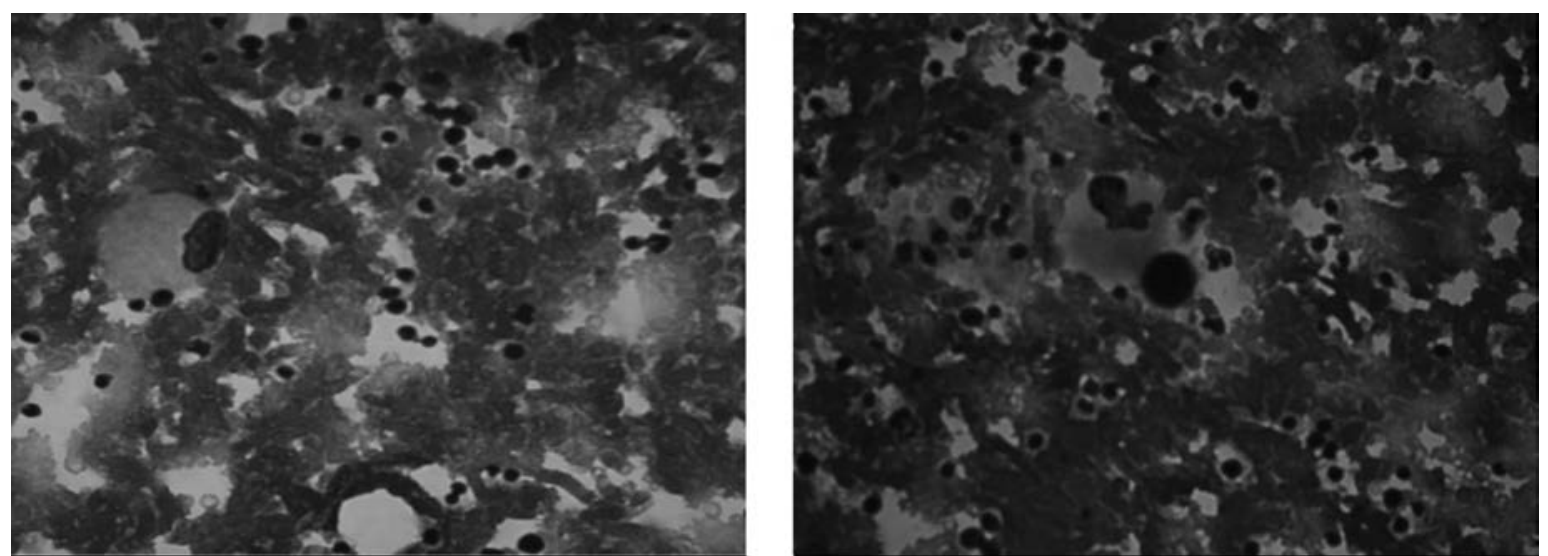

Fig. 2a and 2b. Nonspecific cellular milieu and histiocytic proliferation with the phenomenon of emperipolesis on the histopathologic preparation of bone biopsy sample.

RDD is characterized by an acquired, idiopathic, nonmalignant proliferation of distinctive histiocytes ${ }^{3}$. Painless, massive, bilateral, symmetric, cervical and paratracheal lymphadenopathy associated with the systemic symptoms (fevers, pain, tenderness, malaise, night sweats and weight loss) represents the most common clinical finding. Axillary, paraaortic, inguinal and mediastinal lymph nodes are also commonly affected. Bone marrow, liver and spleen are usually spared ${ }^{1-3}$. Besides affecting of the lymph nodes, about $45 \%$ of cases had at least one site of extranodal involvement. About $20-25 \%$ of cases had extranodal involvement only. The most frequent affecting extranodal sites are skin, soft tissue, nasal cavity and paranasal sinuses (16\%); eye, orbit and bone $(11 \%)$, salivary gland and central nervous system (7\%) and significantly rarer oral cavity, kidney, respiratory tract, liver, tonsil, breast, gastrointestinal tract and heart. Whether nodal and/or extranodal RDD is often under-diagnosed because of a low index of suspicion of this disease ${ }^{1-4}$.

Skeletal lesions are usually multifocal and such involvement is mainly associated with lymphadenopathy and disease in other organs ${ }^{4}$. Patients with the disease who present with a solitary lesion of bone but without additional clinical manifestations are exceedingly rare and the majority of these patients have been in adults 4,20 . A review of the literature reveals approximately 50 cases with solitary bone lesion as the only manifestation of the disease. Lesions arise most frequently in the long bones such as tibia, femur, radius, clavicle, also in the pelvic bones, skull bones, maxilla, mandible and bones of the hands ${ }^{4,20}$.

The present case is a rare example of compression fracture caused by isolated 
Table I. Reported Cases of Extranodal Rosai-Dorfman Disease Localized in the Spinal Column Without Lymphadenopathy

\begin{tabular}{|c|c|c|c|c|c|c|}
\hline $\begin{array}{l}\text { Authors / } \\
\text { year }\end{array}$ & Age & Sex* & Localization** & Symptoms & Treatment & Outcome \\
\hline $\begin{array}{l}\text { Chan et } \\
\text { al./19855 }\end{array}$ & 7 & $\mathrm{~F}$ & $\begin{array}{l}\text { C6 vertebral } \\
\text { pedicle, C6- } \\
\text { T1 epidural } \\
\text { mass, cord } \\
\text { compression) }\end{array}$ & $\begin{array}{l}\text { quadriparesis, neck } \\
\text { pain, torticolis, } \\
\text { difficulty in } \\
\text { urination, anorexia }\end{array}$ & laminectomy & stable \\
\hline $\begin{array}{l}\text { Hollowell et } \\
\text { al. } / 2000^{6}\end{array}$ & 71 & M & $\begin{array}{l}\text { C6- L2 (epidural } \\
\text { mass, cord } \\
\text { compression) }\end{array}$ & $\begin{array}{l}\text { pain, parasthesis, } \\
\text { weakness of legs }\end{array}$ & $\begin{array}{l}\text { incomplete } \\
\text { resection, } \\
\text { steroids }\end{array}$ & $\begin{array}{l}\text { significant } \\
\text { neurologic } \\
\text { improve }\end{array}$ \\
\hline $\begin{array}{l}\text { Hargett et } \\
\text { al. } / 2005^{7}\end{array}$ & 29 & $\mathrm{~F}$ & $\begin{array}{l}\text { T5-T9 (epidural } \\
\text { mass, cord } \\
\text { compression) }\end{array}$ & $\begin{array}{c}\text { progressive } \\
\text { paraplegia, leg pain }\end{array}$ & $\begin{array}{l}\text { pedicle screw } \\
\text { fixation and } \\
\text { fusion, radiation }\end{array}$ & stable \\
\hline $\begin{array}{l}\text { Tubbs et } \\
\text { al./2005 }\end{array}$ & 13 & M & $\begin{array}{l}\text { craniocervical } \\
\text { junction (epidural } \\
\text { mass, cord } \\
\text { compression) } \\
+ \text { mastoid and } \\
\text { parietal bone }\end{array}$ & $\begin{array}{c}\text { neck pain, palpable } \\
\text { neck mass, sinusitis, } \\
\text { mastoiditis }\end{array}$ & $\begin{array}{l}\text { partial resection, } \\
\text { steroids, } \\
\text { antimetabolite } \\
\text { therapy }\end{array}$ & stable \\
\hline $\begin{array}{l}\text { Al-Saad K } \\
\text { et al./2005 }\end{array}$ & 17 & M & $\begin{array}{c}\text { T9 vertebral body, } \\
\text { epidural mass } \\
\text { T8-T10 (cord } \\
\text { compression) }+ \\
\text { tibia }\end{array}$ & $\begin{array}{c}\text { back pain, weakness } \\
\text { of legs }\end{array}$ & $\begin{array}{l}\text { steroids, } \\
\text { laminectomy }\end{array}$ & stable \\
\hline $\begin{array}{l}\text { Robert et } \\
\text { al./200610 }\end{array}$ & 23 & $\mathrm{~F}$ & Sacrum & / & / & / \\
\hline $\begin{array}{l}\text { Huang et } \\
\text { al./200711 }\end{array}$ & 31 & $\mathrm{~F}$ & $\begin{array}{l}\text { T6-T8 (epidural } \\
\text { mass, cord } \\
\text { compression) }\end{array}$ & $\begin{array}{c}\text { paraparesis, back } \\
\text { pain, difficulty in } \\
\text { urination. relapsing } \\
\text { uveitis }\end{array}$ & laminectomy & stable \\
\hline $\begin{array}{l}\text { Gupta et } \\
\text { al./2008 } 12\end{array}$ & 16 & M & $\begin{array}{l}\text { T12 vertebral } \\
\text { body }\end{array}$ & $\begin{array}{l}\text { back pain, leg } \\
\text { numbness, soft } \\
\text { tissue mass }\end{array}$ & laminectomy & stable \\
\hline $\begin{array}{l}\text { Jing et } \\
\text { al./2008 }\end{array}$ & 51 & $\mathrm{~F}$ & $\begin{array}{l}\text { T11 vertebral } \\
\text { body (cord } \\
\text { compression) }\end{array}$ & / & $\begin{array}{l}\text { Fine-needle } \\
\text { biopsy }\end{array}$ & / \\
\hline $\begin{array}{l}\text { Abou-Zeid } \\
\text { et al./2010 }\end{array}$ & 24 & M & $\begin{array}{l}\text { T4-T7 (epidural } \\
\text { mass, cord } \\
\text { compression) } \\
\text { later T8/9 }\end{array}$ & $\begin{array}{l}\text { progressive spastic } \\
\text { paraparesis }\end{array}$ & $\begin{array}{l}\text { laminectomy, } \\
\text { later subtotal } \\
\text { resection with } \\
\text { pedicle screw } \\
\text { fixation }\end{array}$ & $\begin{array}{l}\text { significant } \\
\text { neurologic } \\
\text { improve }\end{array}$ \\
\hline $\begin{array}{l}\text { Raslan et } \\
\text { al./2011 } 15\end{array}$ & 57 & $\mathrm{~F}$ & $\begin{array}{l}\text { T9 (vertebral } \\
\text { body, cord } \\
\text { compression) }+ \\
\text { maxillary sinus }\end{array}$ & back and chest pain & $\begin{array}{l}\text { laminectomy, } \\
\text { radiotherapy }\end{array}$ & stable \\
\hline $\begin{array}{l}\text { Parmar et } \\
\text { al./2013 }\end{array}$ & 64 & M & C6 vertebral body & $\begin{array}{l}\text { pain, weakness of } \\
\text { limbs, parasthesis }\end{array}$ & laminectomy & stable \\
\hline $\begin{array}{l}\text { Kim et } \\
\text { al./201417 }\end{array}$ & 15 & M & $\begin{array}{l}\text { T12 vertebral } \\
\text { body (fracture) }\end{array}$ & back pain & laminectomy & stable \\
\hline $\begin{array}{l}\text { Sciacca et } \\
\text { al. } / 2015^{18}\end{array}$ & 75 & $\mathrm{~F}$ & $\begin{array}{l}\text { T10 vertebral } \\
\text { body (cord } \\
\text { compression) }\end{array}$ & $\begin{array}{c}\text { Paraparesis, } \\
\text { weakness of limbs, } \\
\text { parasthesis }\end{array}$ & $\begin{array}{l}\text { Steroids, hemi - } \\
\text { laminectomy }\end{array}$ & stable \\
\hline
\end{tabular}

${ }^{*} \mathrm{~F}$ - female, $\mathrm{M}$ - male ${ }^{* *} \mathrm{C}$ - cervical, $\mathrm{T}$ - thoracal, $\mathrm{L}$ - lumbal 
extranodal RDD involving the cervical spine without lymphadenopathy and other symptoms. To the authors' best knowledge, solitary lesion in only one vertebral body or vertebral pedicle is described in ten cases $5,8-10,12,13,15-18$, of which in three cases with lesions in other parts (mastoid/parietal bone, tibia, maxillary sinus) $8,9,15$. In three of these cases solitary lesion in one vertebral body is associated with an epidural mass ${ }^{5,8,9}$. Solitary epidural lesion alongside several vertebral bodies is described in another four cases $6,7,11,14$. Vertebral body fracture is an extremely rare manifestation of RDD, which was previously reported in only one case ${ }^{17}$. Only 5 cases were described in childhood $^{5,8,9,12,17}$ and it is interesting that the same number was recorded in the age group over 50 years ${ }^{6,13,15,16,18}$. In Table I, we presented the comparison of all cases of isolated RDD localized in the spinal column. Also, there have been few cases described of intraspinal or intradural involvement, but they did not take into comparison.

Spinal involvement is mostly causing neurologic deficit due to spinal cord compression ${ }^{5-9}$, 11, 13-15, 18. Treatment is also individual. Prognosis of primary osseous RDD is good, although there is no consensus within the medical community for effective treatment. In most cases a neurosurgery intervention, was sulficient while in others it was necessary to administered systemic corticosteroids, radiation therapy and/or chemotherapy (vinca alkaloids or 6-mercaptopurine and oral methotrexate) ${ }^{1-3}$.

RDD shows a variety of imaging manifestations. These lesions are typically intramedullary osteolytic, with either poorly or sharply defined margins, rarely mixed lytic sclerotic or sclerotic. That can be confused radiographically with Langerhans cell histiocytosis ( $\mathrm{LCH}$ ), eosinophilic granuloma or other lymphocyte proliferative diseases. The differential diagnosis also includes bacterial osteomyelitis, fungal infections such as histoplasmosis, metastasis and lymphoma. Other conditions varying from benign to malignant such as giant cell tumor, granulomatous diseases, fibrous dysplasia and Ewing sarcoma/primitive neuroectodermal tumors (PNET) have also been described in the differential ${ }^{3,} 21$.

Juvenile Xanthogranuloma (JXG) and ErdheimCheister disease (ECD) are, like RDD, types of non-langerhans histiocytosis and share some pathological and immunohistochemical features with RDD ${ }^{1}$. Clinically, JXG is a pediatric histiocytosis characterized mainly by xanthomatous skin lesions, but vertebral involvement is rarely seen. On the other hand, ECD is a rare manifestation in childhood and involves multiple organs, with symmetrical long bone involvement, but atypical vertebral involvement with neurological symptoms in children has been described in the literature ${ }^{22}$. These entitles should also be taken into consideration in the differential diagnosis.

There is no specific serological marker for diagnosis. However, patients have an elevated erythrocyte sedimentation rate, leukocytosis with neutrophilia and hypergammaglobulinemia in up to $90 \%{ }^{1-3}$. Our case during active disease had laboratory analysis in the normal range.

Diagnosis of extranodal skeletal RDD rests entirely on biopsies and pathohistological examinations. The most useful immunohistologic marker for SHML histiocytes is the expression of the S100 protein. SHML histiocytes express pan-macrophage antigens (CD68, HAM 56, CD14, CD64, CD15), antigens associated with phagocytosis (CD64), lysosomal activity (lysozyme, alpha-1-antitrypsin) and immune activation (transferring receptor, interleukin-2 receptor). Only rare CD1a positive cells are found in SHML ${ }^{1-3}$. Vertebral involvement and collapse of the vertebral body is a common condition in LCH. Considering that CD1a is a diagnostic marker for $\mathrm{LCH}$, but at times may be false negative and very rarely negative; in unclear cases the determination of langerin (CD207) positivity is important for definitive diagnosis of $\mathrm{LCH}^{23}$. Langerin expression was not done in our case for technical reasons.

Some authors claim that RDD represents the immune deregulatory process. Autoimmune hemolytic anemia as the most frequent immune dysfunction, and polyarthralgia, rheumatoid arthritis, glomerulonephritis and diabetes mellitus are known to complicate SHML ${ }^{1-}$ 3. Immune thrombocytopenic purpura has not yet been described in the literature as a complication of RDD. However, we cannot claim with certainty that this autoimmune process is associated with the underlying disease and ITP should not be considered as 


\section{complication of RDD.}

Extranodal skeletal solitary manifestation of RDD is an extremely rare condition, especially with involvement of the spine vertebra. Because of its rarity, various clinical manifestations and radiologic findings, it was difficult to differentiate from other common diseases on radiologic study alone, so pathologic confirmation was needed. If a young adult or adolescent has compression of the vertebra body, diagnosis of RDD can be considered.

\section{REFERENCES}

1. Haroche J, Abla O. Uncommon histiocytic disorders: Rosai-Dorfman, juvenile xanthogranuloma, and Erdheim-Chester disease. Hematology Am Soc Hematol Educ Program 2015; 2015: 571-578.

2. Allen CE, Kelly KM, Bollard CM. Pediatric lymphomas and histiocytic disorders of childhood. Pediatr Clin North Am 2015; 62: 139-165.

3. Dalia S, Sagatys E, Sokol L, Kubal T. Rosai-Dorfman disease: tumor biology, clinical features, pathology, and treatment. Cancer Control 2014; 21: 322-327.

4. Demicco EG, Rosenberg AE, Björnsson J, Rybak LD, Unni KK, Nielsen GP. Primary Rosai-Dorfman disease of bone: a clinicopathologic study of 15 cases. Am J Surg Pathol 2010; 34: 1324-1333.

5. Chan KW, Chow YY, Ghadially FN, Stansfeld AG, Woo CH. Rosai-Dorfman disease presenting as spinal tumor. A case report with ultrastructural and immunohistochemical studies. J Bone Joint Surg Am 1985; 67: 1427-1431.

6. Hollowell JP, Wolfla CE, Shah NC, Mark LP, Whittaker MH. Rosai-Dorman disease causing cervical myelopathy. Spine (Phila Pa 1976) 2000; 25: 1453-1456.

7. Hargett C, Bassett T. Atypical presentation of sinus histiocytosis with massive lymphadenopathy as an epidural spinal cord tumor: a case presentation and literature review. J Spinal Disord Tech 2005; 18 : 193-196.

8. Tubbs RS, Kelly DR, Mroczek-Musulman EC, et al. Spinal cord compression as a result of Rosai-Dorfman disease of the upper cervical spine in a child. Childs Nerv Syst 2005; 21: 951-954.

9. Al-Saad K, Thorner P, Ngan BY, et al. Extranodal Rosai-Dorfman disease with multifocal bone and epidural involvement causing recurrent spinal cord compression. Pediatr Dev Pathol 2005; 8: 593-598.

10. Robert EG, Fallon KB, Tender GC. Isolated RosaiDorfman disease of the sacrum. Case illustration. J Neurosurg Spine 2006; 4: 425.

11. Huang YC, Tan HY, Jung SM, et al. Spinal epidural Rosai-Dorfman disease proceeding by relapsing uveitis: a case report with literature review. Spinal Cord 2007; 45: 641-644.
12. Gupta P, Babyn P. Sinus histiocytosis with massive lymphadenopathy (Rosai-Dorfman disease): a clinicoradiological profile of three cases including two with skeletal disease. Pediatr Radiol 2008; 38: 721-778.

13. Jing X, McHugh JB, Pu RT. Fine-needle aspiration cytology of Rosai-Dorfman disease of bone. Diagn Cytopathol 2008; 36: 516-518.

14. Abou-Zeid AH, Herwadkar A, du Plessis D Gnanalingham KK. Isolated extradural Rosai-Dorfman disease of the thoracic spine: a rare cause of spinal cord compression: case report. Neurosurgery 2010; 67: E514-E515.

15. Raslan OA, Schellingerhout D, Fuller GN, Ketonen LM. Rosai-Dorfman disease in neuroradiology: imaging findings in a series of 10 patients. AJR Am J Roentgenol 2011; 196: W187-W193.

16. Parmar V, Seward C, Huho A, Qian J, Gandhi R, Pilitsis JG. Rosai-Dorfman disease presenting as cervical radiculopathy. Clin Neurol Neurosurg 2013; 115: 808-810.

17. Kim do Y, Park JH, Shin DA, et al. Rosai-Dorfman disease in thoracic spine: a rare case of compression fracture. Korean J Spine 2014; 11: 198-201.

18. Sciacca S, Barkas K, Heptinstall L, McNamara C, Shetty R. Rosai-Dorfman disease with spinal cord compression: a diagnostic challenge. Eur Spine J 2015; 24 Suppl 4: S529-S535.

19. Rosai J, Dorfman RF. Sinus histiocytosis with massive lymphadenopathy: a newly recognized benign clinicopathological entity. Arch Pathol 1969; 87: 63-70.

20. Orvets ND, Mayerson JL, Wakely PE Jr. Extranodal Rosai-Dorfman disease as solitary lesion of the tibia in a 56-year-old woman. Am J Orthop (Belle Mead NJ). 2013; 42: 420-422.

21. Zaveri J, La Q, Yarmish G, Neuman J. More than just Langerhans cell histiocytosis: a radiologic review of histiocytic disorders. Radiographics. 2014; 34: 2008-2024.

22. Kumandaş S, Kurtsoy A, Canöz O, Patiroğlu T, Yikilmaz A, Per H. Erdheim Chester disease: cerebral involvement in childhood. Brain Dev 2007; 29: 227-230.

23. Kim HK, Park CJ, Jang S, et al. Bone marrow involvement of Langerhans cell histiocytosis: immunohistochemical evaluation of bone marrow for CD1a, Langerin, and S100 expression. Histopathology. 2014; 65: 742-748. 